\title{
QUALITY ASSESSMENT OF INSTRUCTION IN MATHEMATICS PROBLEM SOLVING CLASSES: AN EVALUATIVE INSTRUMENT
}

\author{
Maria Alice Veiga Ferreira de Souza ${ }^{1}$ \\ Julia Schaetzle Wrobel ${ }^{2}$ \\ Vanessa Ribeiro Gaigher ${ }^{3}$
}

\begin{abstract}
This study aims at presenting our efforts to build a methodological tool to assess the quality of teaching in a math problem solving lesson based on Lesson Study method, and to contribute to practical orientation of the pre-service and in-service mathematics teachers. We rely on authors of mathematics education who studied problem solving, teaching practice and the performance of students. The instrument called "Quality Assessment of Instruction in Problem Solving" (QAIPS) was validated in the qualitative and interpretative ways. Some items that construct the instrument are here justified through empirical situations, which brought to the front discussions that expanded the analysis of the instrument. The QAIPS proved potential for the desired purposes.
\end{abstract}

Keywords: Quality. Teaching. Problem Solving. Lesson Study. Instrument.

\section{QUALIDADE DO ENSINO EM AULAS DE RESOLUÇÃO DE PROBLEMAS DE MATEMÁTICA: UM INSTRUMENTO AVALIATIVO}

Resumo: Esse estudo destina-se a apresentar nossos esforços na construção de um instrumento metodológico para avaliar a qualidade do ensino de uma aula de resolução de problemas de Matemática baseada no método Lesson Study, e que contribua para a formação inicial e/ou continuada de professores de Matemática na/da prática. Apoiamo-nos em autores da Educação Matemática que estudaram resolução de problemas, a prática docente e o desempenho de estudantes. O instrumento Quality Assessment of Instruction in Problem Solving (QAIPS) foi validado pela via qualitativa e interpretativa. Alguns itens que compõem o instrumento são aqui justificados por meio de situações empíricas, que trouxeram à frente discussões que ampliaram as análises do instrumento. O QAIPS mostrou-se potencial para os fins almejados.

Palavras-chave: Qualidade do Ensino. Resolução de Problemas. Estudo de Aula. Pesquisa de Aula. Instrumento.

1 Federal Institute of Espírito Santo - IFES. alicevfs@gmail.com

2 Federal University of Espírito Santo - UFES. juliasw@gmail.com

3 Federal Institute of the Espírito Santo - IFES. van_gaigher@yahoo.com.br 


\section{CONTEXTUALIZING THE DISCUSSION}

How can we evaluate the quality of teaching a lesson based on math problems solving? What factors in teaching should be considered for this evaluation? The search for answers to these questions by the authors of this article demanded extensive literature research to gather arguments that support the elaboration of an instrument that evaluates the quality of teaching based on problem solving and contributes to the pre-service and in-service mathematic teachers training for the practice of teachers' classes.

The structure of the instrument, from now on called Quality Assessment of Instruction in Problem Solving (QAIPS), is based on recommendations from authors and researchers from de scientific community of mathematics education who have studied different topics: problem solving in the context of mathematics classes, teaching practice in math problems solving, teaching quality and quality assessment, training of the teacher practice and terms and concepts that tangent discussion and that should be clarified in this context - problem versus exercise, reading comprehension, resolution strategy, mathematics symbology domain, among others.

For convenience, the code of the questions that make up the QAIPS will be indicated throughout the text, next to the argument/discussion that supported their inclusion, facilitating the recognition by the reader of the reasons of their relevance. The indications occur as often as it is mentioned by different authors and appear in the text in brackets with the numeric ID of the item in the questionnaire located at Table 2 in the end of this article (Q1, Q2, .., Q46). For example, Q1 is QAIPS' question number one: Were the criteria for choosing the problem presented on the teacher's planning?

Briefly, the article is guided by recommendations of elements considered relevant by the scientific community of mathematics education. These recommendations are reflected in the 46 elements of QAIPS subsequently validated in a Lesson Study environment, that aim, therefore, to evaluate the quality of classes based on problem solving. 
Figure 1 - Investigation scheme.
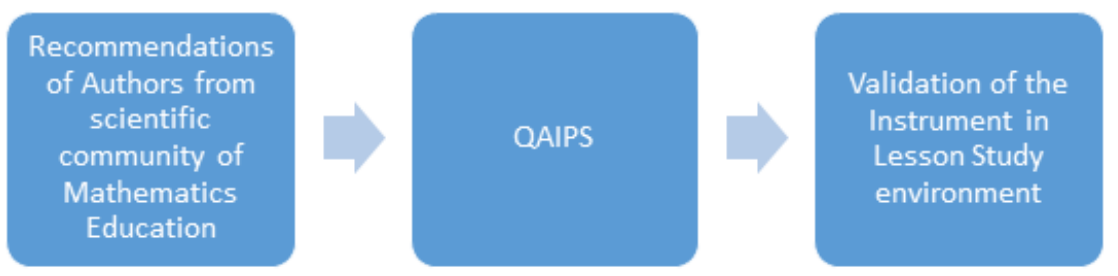

Source: authors.

\section{ABOUT PROBLEMS RESOLUTION IN MATHEMATICS CLASSES CONTEXT}

Problem solving is an old concern of researchers in mathematics education by declaring its little evidence in mathematics curricula in many countries since the $\mathrm{XX}$ century: Portugal (ABRANTES, 1989, 1989b) United States (SCHOENFELD, 1996), France (REVUZ, 1978), Thailand (PURAKAM, 1978), Australia (BLAKERS, 1978), Brazil (ALLEVATO, ONUCHIC, 2005), etc. Whether as content, in the broad sense of the word, or as a teaching method of mathematical objects, problem solving was sometimes timidly indicated in documents that guided the school curricula, or implicitly, sometimes overtly as the focus of Mathematics school by the National Council of Teachers of Mathematics (1980), Portuguese Basic School Math Program (MINISTÉRIO DA EDUCAÇÃO, 2007) and by the National Curriculum Parameters (BRASIL, 2000), in the case of Brazil.

Anyway, these intentions do not seem to have been carried out in mathematics classrooms as a practice inherent in this discipline, perhaps the character of unpredictability and insecurity own resolution process, because "solve a problem means consciously seek some appropriate action to achieve a clearly defined objective, but not immediately attainable” (SOUZA; GUIMARÃES, 2015, p.137), which leads to require use of all incorporated mathematical potential so far. In this context, it is not possible to talk about a problem but about an exercise executed with very low or no cognitive effort.

The emerged benefits of problem solving classes for learning mathematical content has been defended by the same authors and researchers mentioned above. Problem solving can develop in students a critical and autonomous view - attitudinal characteristics - as well as to be able to 
potentiate mathematical reasoning, on the cognitive side. As a teaching and learning via (Q26), or as an application of mathematical content (Q27) or, simply as a motivation for mathematics classes, researchers in mathematics education (SOUZA; GUIMARÃES, 2015; SCHOENFELD, 1996) argue that classes based on problem solving can strengthen in students' domain procedures and use of various knowledge to solve different situations. In addition, Schoenfeld (1996) highlights the value of problem solving for the awakening of a mathematical culture in the school environment, developing in students the ability to expand the limits of their mathematical thinking and emphasizes the importance of this pathway for communication by mathematics language (Q33, Q34, Q35).

Regarding these classes, we agree with Polya (1973) when this author says that the teacher should encourage students to think about the problem, to understand it, to establish solving strategies and analyze the solution together (Q10, Q11, Q13, Q14, Q15, Q16, Q17, Q22, Q23, Q28, Q39, Q40, Q41), besides requiring more efficient means to already prepared. Steps that make up a math problem solving, according to Polya (1973): 1 - understanding the problem; 2- elaborating a plan for its resolution; 3- executing the plan, and; 4- looking back. The teacher must consider these steps and conduct the student to investigate through relevant questions (Q4, Q18, Q19, Q20) in order to make a plan to execute actions that lead to solve the problem, thus promoting a learning that stimulates specific reasoning.

Polya (1973) clarifies not be possible to respond to something proposed if the problem is not understood correctly (first step) (Q3, Q43). It is necessary that the issue is well written, planned (second step) (Q5, Q6, Q44) and that the level of difficulty is adapted to the class level of knowledge (Q1, Q2).

The problem should not be too easy or too difficult, as both cases can discourage students. Problems very easy do not challenge or instigate their curiosity, and the difficult ones may become so complex that discourage the participation of the individual. In addition, the student must identify the main parts of the problem, the unknown, the data and the condition. Polya (1973) recommends that, rarely, the teacher can dismiss the questions: What is the unknown? What are the data? What is the condition? To establishing a plan: "Do you know a related problem? [...] Do you know a 
theorem that could be useful? [...] try to think of a familiar problem having the same or a similar unknown [...] Could you restate the problem? [...]” (POLYA, 1973, p.xvi) (Q4, Q22, Q23, Q44).

The questions suggested by the author are important to stimulate the reasoning flow through the math resolution (third step). But not every question is relevant. Broad questions can block students' thinking and have an effect opposite to the desired by the teacher, as reported Wrobel et al. (2016) in their investigations (Q21).

Moreover, Polya (1973) affirms not be easy to establish an action plan to solve a problem. The transition path between understanding the problem and defining a plan of action can be long and laborious. The author also highlights that every good teacher must understand that no problem is completely exhausted and it is possible to find new ways to achieve the goal of the proposed problem (fourth step) (Q7, Q11, Q37, Q40, Q41). In this search, new concepts can be built; new ideas can emerge and may be cause for validations or refutations that occurs in Mathematics (Q46).

From the analysis of the resolution process, the student experiences the opportunity to reflect on the ways and methods chosen by him to solve the problem, which, in turn, lead to the discovery of the essence of it, leading it to a process of generalization of the given problem, or, for use in problems with similar characteristics. The teacher can also take advantage of the step of elaboration of strategies to analyze the nature of the error made by the student (Q14, Q42). It is possible that the teachers investigate this process and identify the type of mistake that thus can (re) think their practice to act with more effectiveness in student learning, promoting the development of autonomy and criticality (Q29).

In addition to the promotion and training of autonomy and criticality of the students, the resolution of problems is an ally to teaching work that seeks the formation of individuals acting actively in society. If on one hand the resolution of problems has this immense potential for teaching and learning of mathematical content, on the other, brings an uncertain character and unpredictability to the lessons that can be minimized with collaborative teaching practices, which we will continue in our discussion.

\section{THE TEACHING PRACTICE}


Any class, and in particular classes based on problem solving, should be carefully planned, predicting the impact and reactions of students from the teacher's interventions. Some ingredients for this class are well described by Japanese authors that integrate the scientific community of mathematical educators which contributed to the elaboration of the QAIPS. These indications are being implemented in many countries such as the APEC (Asia-Pacific Economic Cooperation), African Nations and European countries, plus the United States, as says Fujii (2014).

Baldin (2009) affirms that teaching practice must focus on the evaluation of effective and participatory student learning. This can be accomplished by researching of a class, or a sequence of classes, teachers and people interested in the methodological progress of math classes aimed at the potential of student learning, always in a collaborative and reflexive mode (Q10, Q11, Q28, Q30, Q37, Q39, Q40, Q41). Ponte et al. (2015) point out that should be worried about the content they teach, curriculum guidelines, reasoning processes and difficulties of students and the dynamics of the classroom (Q6, Q10, Q18, Q19, Q29).

Japanese authors as Fujii (2014), Fernandez and Yoshida (2004) and Isoda and Olfos (2009) declare that the class' planning should be done around a challenging problem, involving a preestablished content. We must consider the student as a central agent of learning with active participation. For the choice of the problem or issue, you need intensive research on the mathematics involved and previous knowledge of students. Those involved should share ideas and draw the best plan design, inspired on experience, in manuals and books (Q1, Q2, Q5, Q10, Q11, Q12, Q17, Q22, Q23, Q26, Q27, Q30, Q37, Q39, Q40, Q41).

Thus, teachers will have a deeper understanding of the problem and the proposed content for that planning, contributing both to the construction of specific knowledge to teach mathematics, and, to make students learn in a more comprehensive way. Fujii (2014) recommends the joint elaboration and raised discussions about what situations will be proposed to begin the lesson and why (Q1). Fernandez and Yoshida (2004) and Isoda and Olfos (2009) add that teachers should be worried if the proposal is appropriation to the context of the students, which questions will be made to get them to think, which answers are expected to these questions, what questions might arise, which epistemological obstacles will be found as well as the methodological alternatives, including by providing multiple representations or multiple strategies for the solution process, connecting 
them, and designing assessment for different steps. Here are some wires for the QAIPS brought by (Q2, Q4, Q5, Q8, Q9, Q13, Q14, Q15, Q16, Q20, Q21, 28, Q29, Q42, Q43, Q44, Q45, Q46).

When dealing with different solution strategies for the same problem, it is worthwhile noting the importance of this feature, because Souza and Guimarães (2015) bring us clarification on various mental representations that may come out, depending on how it is proposed. Different solution strategies can be formulated by students from the generation of different models of mental representation, extending the repertoire of solution possibilities by the connections to be established. Besides that, this may be a reason for the recovery or revision of past mathematical contents (Q8, Q9, Q20, Q24, Q25). In other words, depending on how the teacher presents the initial work, different ways of thinking may arise and hence different solution strategies can be proposed by them, including the mental block (WROBEL at al., 2016; SOUZA, 2017; SOUZA; SOUZA, 2016), consisting then in another item to be considered in the QAIPS (Q20, Q21).

Therefore, the initial work goes beyond a simple planning and on which Baldin (2009, p.2) agrees saying that "rarely, the lesson plans contain this level of detail, nor are reviewed after classes, except possibly for the record that some content has not been not executed". To achieve these goals, Fujii (2014) recommends that teachers be immersed in a continuing education whose debate becomes rich due to the sharing of information and experiences ${ }^{4}$. On the implementation of the class, Fujii (2014) warns that unforeseen events may occur and that the teacher should have the plan as a thread of their actions and not with a script to be followed ipsis verbis (Q38).

Training in teacher practice is essential in this work. In this regard, Ponte (2014) points out aspects that emerge from the professional development of a teacher: collaboration, practice as the starting point of the training, focus on student learning, integration between content and pedagogy and professional research. The collaboration takes on a perspective of voluntary participants who propose to take common goals, to be really involved and work is revealed in collective character, in the sense that everyone has something to learn and to teach. According to Ponte (2014), the professional learning is constructed through the exchange of knowledge, and collaborative work is a means to solve common problems (Q12).

4 By the way, in Japan, according to Fernandez and Yoshida (2004) and Isoda and Olfos (2009), these teachers' practice lends itself to the initial training when undergraduate or recent graduate teachers are members of these groups. 
The role of practice as a starting point for the formation, in turn, becomes important to take the training process to a real context, combining the experience of reality, as a professional, with the course to which the teacher is inserted. Ponte (2014) warns that this is not overvaluing the practice and disconnects training theories. Both should be worked together to enrich the full exercise of the teaching profession.

On the side of the student, the teacher's role is to know and to work from the difficulties/facilities for learners to come across concepts, representations and mathematical procedures (Ponte, 2014) (Q8, Q9, Q24, Q25, Q26, Q27, Q30, Q33, Q34). Therefore, it is crucial that the teacher be aware and careful about everything that he/she proposes to the classroom. His/her planning should be focused on student learning, because he/she - the teacher - is responsible for selecting carefully the activities, for investigating the students' prior knowledge, as well as trying to predict the difficulties and epistemological obstacles that may be encountered by his students (Q1, Q2, Q3, Q5).

Combining the mathematical content and teaching is an aspect underlined by Ponte (2014). For him, knowing deep mathematics is necessary for teaching quality, but not enough. The teacher should integrate his/her specific knowledge of the mathematics with the pedagogical knowledge in order to meet the needs that will arise from the present difficulties in the teaching profession. The pedagogical knowledge "helps to understand the student, their learning processes and contexts that favor them” (PONTE, 2014, p.350-351).

The connection between these two kinds of knowledge, however, is not immediate and some issues must be observed, because

\begin{abstract}
the teacher and pre-service teacher better understand a concept or mathematical representation, looking at its role in various levels of education programs, thinking of the tasks that you can use for teaching, analyzing different resolutions of the students and observing their difficulties in understanding this concept, then learning the concept of totally abstract form, as it appears in a math book. They learn better mathematics and the problems of education if they are interlinked, guiding the realization of professional practice situations and providing moments of reflection in which deepen the mathematical concepts involved and learning processes, the light of work carried out by the teacher himself (PONTE, 2014, p.351, translated and italic by authors) (Q1, Q8).
\end{abstract}

These aspects require a strong investigative work on the problems of teaching - another aspect listed by Ponte (2014). It is the guiding thread that weaves together all the aspects discussed above. 
Through research, you can identify the problems of professional practice and ways to solve them, while also promoting a learning process in which teachers have the opportunity to discuss and intervene significantly on the practice itself, resulting in a remarkable learning for teachers and contributing to their professional identity.

\section{THE QUALITY OF TEACHING AND THE QUALITY OF ASSESSMENT}

When thinking of a process of teacher training as an active agent in their professional development, Ball, Thames and Phelps (2008), members of the group Hill et al. ${ }^{5}$ (2011) developed a practice-based theory of content knowledge for teaching supporting the arguments of Shulman (1986), deepening them. To this end, Ball, Thames and Phelps (2008) initiated a project focused on the work teachers do in teaching mathematics trying to understand the nature of mathematical knowledge to be taugh. They started their investigations not for the implications of teaching on knowledge, but for what teaching itself requires.

In this sense, Ball and her colleagues investigated the knowledge necessary to master the teaching act in the teachers' own practice, thus refining Shulman's (1986) arguments about the pedagogical knowledge of content and the knowledge of the content for teaching. For Shulman (1986), knowing how to teach is more than knowing concepts, rules and procedures. It is necessary to place this content historically, and know why and what to teach a certain subject, comprehending it deeply, knowing relations between the curriculum in Mathematics and other disciplines, as well as understanding the different representations of the same content, their analogies, examples and counterexamples, demonstrations, degree of difficulty and worry about the experiences that students bring with them. In a way, this view is shared by Schön (1991, 1992), Elbaz (1983), Fenstermacher (1994) and Clandinin $(1985,1986)$ to defend the existence of a knowledge that emerges from the teaching practice, and contrary to the idea of a technical sense translated as a pure and simple application of scientific and technical knowledge to practical environment.

Ball, Thames and Phelps (2008), together with Hill et al. (2011), analyzed the practice of teaching and developed survey measures of content knowledge for teaching mathematics. "The

5 Learning Mathematics for Teaching (LMT) project, which at that time had the following researchers: Heather C. Hill, Deborah Loewenberg Ball, Hyman Bass, Merrie Blunk, Katie Brach, Charalambos Y. Charalambous, Yaa Cole, Carolyn Dean, Sea'n Delaney, Sam Eskelson, Imani Masters Goffney, Jennifer M. Lewis, Geoffrey Phelps, Laurie Sleep, Mark Thames and Deborah Zopf. 
measures provided a way to investigate the nature, the role, and the importance of different types of mathematical knowledge for teaching” (BALL; THAMES; PHELPS, 2008, p.390). Thus, the authors opted for an investigative approach to the practice of teachers aimed at answering the question: What teachers need to know and be able to do in order to teach mathematics effectively?

By focusing on the study of teacher practice, Ball, Thames and Phelps (2008) found that the mathematical demands of teaching were substantial. The mathematical knowledge that a teacher of this area needs is different from the mathematical knowledge of other professionals. By way of illustration, they consider that subtraction 307-168 is simple for most people. The authors called “common content knowledge (CCK) and define it as the mathematical knowledge and skill used in settings other than teaching” (BALL; THAMES; PHELPS, 2008, p.399).

Mathematics teachers should be able to identify the answers given by the students, in addition to know how to calculate. Teachers need to master the content they teach, be able to identify wrong answers, or even identify some inaccurate definition in textbooks. The act of teaching requires that the teacher goes beyond identifying his/her student's error and understands the source of the mathematical error. Identify, understand, help and correct the error of the student are tasks of the teacher's routine (HILL et al., 2011). The simple identification of an error does not enable for an efficient and skillful treatment of the problems faced by students and this is a difference between a mathematician - analyzes his/her own mistakes - and a teacher of Mathematics - analyzes errors produced by students (Q29).

In addition to the error, it is necessary to consider the diversity of alternative approaches of students before proposing the task. It is common for a student to propose a solution different from that expected by the teacher. In this case Ball, Thames and Phelps (2008, p.397) point out that "They [teachers] have to figure out what students have done, whether the thinking is mathematically correct for the problem, and whether the approach would work in general.” (Q30, Q39, Q40, Q41, Q44, Q45). Get involved in this type of issue, provide mathematically correct answers and explain the procedures involved are basilar factors in the teaching profession.

The specialized content knowledge has been seen by Ball, Thames and Phelps (2008, p.400) as "the mathematical knowledge and skill unique to teaching". This area comprises all the requirements for education and differs from knowledge indispensable in other scenarios. Therefore, 
it is crucial that there is a bridge between the knowledge of the academic world and the world of school practice because, to perform the teaching profession with mastery, the teacher needs something beyond the mathematical knowledge taught in his/her undergraduation.

This articulation between different knowledge is defined by Ball and Bass (2003) through the metaphor of "unwrapping” knowledge. For them, it is essential that the teacher "unwraps" his/her own formal knowledge to understand the student's knowledge. It is up to him/her to "unwrap" knowledge produced by the student to deeply understand the structures designed by them. The teacher should be able to predict the possible thoughts, reasoning, doubts, facilities and misconceptions of students (Q3, Q5).

The knowledge of content and teaching refers to the combination between knowledge about teaching and knowledge about mathematics. Ball, Thames and Phelps (2008, p.401) explain that,

\begin{abstract}
Many of the mathematical tasks of teaching require a mathematical knowledge of the design of instruction. Teachers sequence particular content for instruction. They choose which examples to start with and which examples to use to take students deeper into the content. Teachers evaluate the instructional advantages and disadvantages of representations used to teach a specific idea and identify what different methods and procedures afford instructionally. Each of these tasks requires an interaction between specific mathematical understanding and an understanding of pedagogical issues that affect student learning. (Q1)
\end{abstract}

The arguments presented in this section led Hill et al. (2011) to develop and validate an instrument for measuring of the quality of Mathematics content teaching, called Mathematical Quality of Instruction (MQI). The MQI is supported by six major constructs: 1) Richness and development of the mathematics; 2) Responding to students; 3) Connecting classroom practice to mathematics; 4) Language; 5) Equity; 6) Presence of unmitigated mathematical errors.

When working the richness and development of mathematics, the authors of MQI explored various types of representations (or mathematical models) - visual, concrete, verbal, symbolic - and as far as possible guide to link each other (Q8, Q9, Q24, Q25). Also, they suggest that students should have access to precise mathematical meaning, with explanations and justifications necessary for their understanding and the mathematical language, reasoning and practices (Q19, Q27, Q31, Q33, Q34, Q35). The second construct presented by Hill et al. (2011) refers to the ability to responsiveness to student ideas and misconceptions. While some teachers can discern precisely the mathematical ideas presented by students (right or not), others misinterpret such statements, having 
severe difficulties in the classroom. Another pertinent question about the error is whether and how teachers use misunderstandings of students in the context of the classroom (Q36, Q38). On the third construct, the authors point out that an issue that permeates the practice connection in mathematics classes is that real life problems or manipulative materials are often used feebly, without a specific mathematical purpose (Q31). The authors constructed a set of codes to capture this aspect of education, namely: if during work the students were involved with a mathematical idea or procedure; the mathematical content is developed during the lesson or if the focus is lost and the proportion of instructional time effectively spent on mathematics (Q10, Q23, Q26, Q28, Q30, Q32).

The language appears as the fourth construct in which Hill et al. (2011) bothered to know more about conventional notation and technical language, that is, if symbols (e.g., =, 7 or $\Delta \quad$ ) and terms (e.g., vertex, function or commutative) are appropriately presented and used in the instruction. In addition, it makes a difference whether terms or notation are simply used during instruction or whether there is an explicit talk about their meaning. There is also a concern on the use of general language to express mathematical ideas and potential misinterpretation by students (e.g., a fair coin) (Q33, Q34, Q35).

On the fifth construct (equity), the teacher should ensure that all students have access to mathematics that occurs in the classroom and be sensitive to differences among students' preexisting mathematical foundations. Teachers must give the opportunity for all to participate and learn (Q28, Q30, Q39). In addition, mathematically poor lessons in which students engage in unproductive work because of poorly formulated tasks or inefficient management of the classroom are doubly prejudicial for students. There is still an emotional/affective dimension involved: while some students arrive in the classroom feeling confident of their skills, others need special encouragement and recognition of their mathematical contributions. These codes of equity, therefore, provide an idea of the teacher's work to increase student access to mathematical ideas and for the emotional/affective environment they are trying to promote to their students. Finally, it is undeniable that teachers make mistakes in mathematics classes and the authors have designed codes to capture computational errors or significant omissions, such as presenting incomplete, inaccurate or incorrect of a concept, of mathematical language, of representations or an incorrect procedure (Q36). 
The evaluation of events belonging to the MQI constructs was determined from four options: present and appropriate, present and inappropriate, not present and appropriate, and not present and inappropriate (Table 1). If an educational element was present and this presence was considered appropriate, it would be rated as "PA"; if present, but it was considered inappropriate, "PI"; on the contrary, if there is omission of the element and its absence is considered appropriate, it would be rated as "NP-A"; otherwise, "NP-I".

In specific situations, just two options were possible, such as the construct "equity" whose options were present/not present, not making sense the use of appropriate/inappropriate.

The MQI is one of the bases for the structuring of the QAIPS for its character integrally focused on the teaching practice in mathematics classes. Although the MQI is a quantitative assessment tool, it needed an argument that would delineate the constructs that compose it, qualitative aspect that is prior to quantitative. The QAIPS has qualitative bias, because we investigated the relevant events in the case of problem-solving classes and not any Mathematics class. These specific classes have peculiarities and, for that reason, therefore, only aspects of the MQI that were in tune with the purposes of the QAIPS were useful for its construction.

\section{THE QAIPS}

Dias Sobrinho and Ristoff (2016, p.11, our translation) argue that "on the one hand, evaluation is conceived and carried out primarily for regulation and control. On the other hand, evaluation is conceived and practiced, at least at the level of intention, as an instrument of emancipation". We understand evaluation as a permanent process and a support mechanism for the promotion of classes that favor the development of the student's autonomy, criticality and exercise of citizenship. In this sense, QAIPS sought to gather ideas that articulate premises and actions for what is understood as quality of a class based on problem solving, and can be a useful tool for the practice of teachers.

The instrument is supported by pillars built from arguments and rationales authors of mathematics education who studied teaching practice and the performance of students by the effects of the actions of their teachers. These studies were published in books and papers and were mentioned previously because they justify the presence of each item in the QAIPS. It is therefore an 
investigation whose product (QAIPS) was built with bibliographic support and validated through a qualitative and interpretative work (BOGDAN; BIKLEN 1994), relying on the participant observation, one of the social sciences research strategies (JORGENSEN, 1989).

The arguments brought from the theoretical and literary support that justify the inclusion of each item in QAIPS are also included in Table 1 in a specific column in the form of an exposed code on the label, because of its practicality. The items that comprise the QAIPS are distributed in Table 2, not by chance, as we believe that the search for class quality is directly linked to what is done before and during the teacher's actions.

Table 1 - Labels about the theoretical and literary support for the items in Table 3.

\begin{tabular}{c|l|c|l}
\hline Code & \multicolumn{1}{|c|}{ Reference } & Code & \multicolumn{1}{c}{ Reference } \\
\hline a & Baldin (2009) & g & Polya (1973) \\
\hline b & Ball; Thames; Phelps (2008) & h & Ponte (2014) \\
\hline c & Fernandez; Yoshida (2004) & i & Schoenfeld (1996) \\
\hline d & Fujii (2014) & j & Souza; Guimarães (2015) \\
\hline e & Hill et al. (2011) & k & Souza; Souza (2016) \\
\hline f & Isoda; Olfos (2009) & l & Wrobel et al. (2016) \\
\hline
\end{tabular}

Source: authors.

Table 2 - Instrument of Quality Assessment of Instruction in Problem Solving (QAIPS).

\begin{tabular}{c|l|l}
\hline Item & $\begin{array}{c}\text { Theoretical/literary } \\
\text { support }\end{array}$ & \multicolumn{1}{c}{ Questions } \\
\hline Q 1 & b, c, d, f, g, h & $\begin{array}{l}\text { Planning Lesson Stage } \\
\text { Were the criteria for choosing the problem presented on the } \\
\text { teacher's planning? }\end{array}$ \\
\hline Q 2 & c, f, g, h & $\begin{array}{l}\text { Has the teacher predicted the students' familiarity with the } \\
\text { context of the problem? }\end{array}$ \\
\hline Q 3 & b, g, h & $\begin{array}{l}\text { Has the teacher planned any action to check possible obstacles } \\
\text { in understanding the problem? }\end{array}$ \\
\hline Q 4 & c, f, g & $\begin{array}{l}\text { Did the teacher prepare questions for the steps of understanding, } \\
\text { planning, executing and looking back? }\end{array}$ \\
\hline Q 5 & b, c, f, g, h & $\begin{array}{l}\text { Did the teacher predict reactions and responses of the students to } \\
\text { the questions that guided them to solve the problem? }\end{array}$ \\
\hline Q 6 & g, h & $\begin{array}{l}\text { Has the teacher drawn a line of conduct for his/her performance } \\
\text { in conducting the problem solving class? (That is, did he } \\
\text { schedule a lesson for him/her to lead?) }\end{array}$ \\
\hline
\end{tabular}




\begin{tabular}{|c|c|c|}
\hline Q 7 & g & $\begin{array}{l}\text { Has the teacher planned more than one problem solving } \\
\text { strategy? }\end{array}$ \\
\hline Q 8 & $c, e, f, h, j, k$ & $\begin{array}{l}\text { Has the teacher been concerned with multiple mental } \\
\text { representations (visual, concrete, verbal, symbolic etc.) or } \\
\text { multiple mathematical strategies in solving the problem? } \\
\text { (Geometry, algebra, count, scheme, table, figure, etc.) }\end{array}$ \\
\hline Q 9 & c, e, f, h, j, k & $\begin{array}{l}\text { Has the teacher planned to connect multiple representations } \\
\text { and / or mathematical strategies? }\end{array}$ \\
\hline Q 10 & a, c, e, f, g, h & $\begin{array}{l}\text { Did the teacher plan the construction of the mathematical } \\
\text { resolution with the students? }\end{array}$ \\
\hline Q 11 & a, c, e, f, g & $\begin{array}{l}\text { Has the teacher planned to review the problem with students in } \\
\text { order to find more efficient solutions (shorter, more elegant, and } \\
\text { that use more basic content)? }\end{array}$ \\
\hline Q 12 & $c, f, h$ & $\begin{array}{l}\text { Did the teacher share/discuss his/her resolution with other } \\
\text { professionals or people so that he/she could prepare the } \\
\text { planning? }\end{array}$ \\
\hline Q 13 & $c, f, g$ & $\begin{array}{l}\text { Has the teacher planned how he/she will evaluate students' } \\
\text { success/failure on understanding the text of the problem? }\end{array}$ \\
\hline Q 14 & $c, f, g$ & $\begin{array}{l}\text { Has the teacher planned how he/she will evaluate the } \\
\text { success/failure of students in problem solving planning? }\end{array}$ \\
\hline Q 15 & c, f, g & $\begin{array}{l}\text { Has the teacher planned how he/she will evaluate students' } \\
\text { success/failure on mathematical performance of the problem? }\end{array}$ \\
\hline Q 16 & $c, f, g$ & $\begin{array}{l}\text { Has the teacher planned how he/she will evaluate the } \\
\text { success/failure of students in looking back at the problem? }\end{array}$ \\
\hline \multicolumn{3}{|c|}{ Execution Lesson Stage - Substage Problem Presentation } \\
\hline Q 17 & c, f, g & $\begin{array}{l}\text { Did the teacher examine the familiarity of students with context } \\
\text { of the problem? }\end{array}$ \\
\hline Q 18 & g, h & $\begin{array}{l}\text { Did the teacher check words, expressions and passages capable } \\
\text { of blocking in understanding flow problem by students? }\end{array}$ \\
\hline Q 19 & e, g, h & $\begin{array}{l}\text { Has the teacher clarified words, expressions and passages that } \\
\text { could be blocked in understanding of flow problem by students? }\end{array}$ \\
\hline Q 20 & $c, f, g, j, k, l$ & $\begin{array}{l}\text { Did the teacher ask broad questions that would block the } \\
\text { students' understanding of the problem? }\end{array}$ \\
\hline \multicolumn{3}{|c|}{ Execution Lesson Stage - Substage Solving Process } \\
\hline Q 21 & $c, f, l$ & $\begin{array}{l}\text { Did the teacher ask broad questions that blocked the reasoning } \\
\text { flow of students and the mathematical strategies? }\end{array}$ \\
\hline Q 22 & c, f, g & $\begin{array}{l}\text { Did the teacher find out if the students knew a similar problem } \\
\text { or if they could reformulate it? }\end{array}$ \\
\hline Q 23 & c, e, f, g & $\begin{array}{l}\text { Did the teacher ask if the students associate some mathematical } \\
\text { content to that problem? }\end{array}$ \\
\hline Q 24 & $\mathrm{e}, \mathrm{h}, \mathrm{j}, \mathrm{k}$ & $\begin{array}{l}\text { Has the teacher used multiple representations or mathematical } \\
\text { strategies in the conduction of problem solving? }\end{array}$ \\
\hline
\end{tabular}




\begin{tabular}{|c|c|c|}
\hline Q 25 & e, h, j, k & $\begin{array}{l}\text { Has the teacher made connections between multiple } \\
\text { representations or mathematical strategies? }\end{array}$ \\
\hline Q 26 & c, e, f, h, i, j, k & $\begin{array}{l}\text { To solve problems as a way of learning content: did the teacher } \\
\text { favor the student's construction of desired mathematical } \\
\text { concept(s)? }\end{array}$ \\
\hline Q 27 & e, h, i, j, k & $\begin{array}{l}\text { For problem solving as a content application: has the teacher } \\
\text { taken over the mathematical concepts involved in the problem } \\
\text { for his/her application? }\end{array}$ \\
\hline Q 28 & a, c, e, f, g & $\begin{array}{l}\text { Did the teacher play and appreciate the intellectual production } \\
\text { of the students for the joint construction of the resolution of the } \\
\text { problem? }\end{array}$ \\
\hline Q 29 & $c, e, f, g, h$ & $\begin{array}{l}\text { Has the teacher made the students' mistakes as an element for } \\
\text { building reasoning by class? }\end{array}$ \\
\hline Q 30 & a, b, c, e, f, h & $\begin{array}{l}\text { Has the students' work been engaged during the connections of } \\
\text { the mathematical idea or the mathematical procedure? }\end{array}$ \\
\hline Q 31 & e & $\begin{array}{l}\text { Has the mathematics involved in the issue been developed over } \\
\text { the reasoning without getting lost along the way? }\end{array}$ \\
\hline Q 32 & e & $\begin{array}{l}\text { Was teaching time effectively consumed with mathematics and } \\
\text { problem solving? }\end{array}$ \\
\hline Q 33 & e, h, i & $\begin{array}{l}\text { Was conventional mathematical notation used correctly during } \\
\text { teaching? }(=, \neq, \pm, \div \text {, etc. })\end{array}$ \\
\hline Q 34 & e, h, i & $\begin{array}{l}\text { Were mathematical terms properly used for teaching? (vertex, } \\
\text { function, unknown, variable etc.) }\end{array}$ \\
\hline Q 35 & $\mathrm{e}, \mathrm{i}$ & $\begin{array}{l}\text { Has the teacher abused mathematical language to convey ideas } \\
\text { and mathematical concepts? }\end{array}$ \\
\hline Q 36 & e & $\begin{array}{l}\text { Has the teacher made mathematical errors, such as calculations, } \\
\text { significant omissions, inaccurate content presentation, incorrect } \\
\text { procedure, without correction during the class? }\end{array}$ \\
\hline Q 37 & a, c, f, g & $\begin{array}{l}\text { Did the teacher asked/conducted a review of the problem for } \\
\text { more efficient solutions and inaccuracies check? }\end{array}$ \\
\hline Q 38 & d, e & $\begin{array}{l}\text { Has the teacher been able to deal with elements that were not in } \\
\text { class planning? }\end{array}$ \\
\hline \multicolumn{3}{|c|}{ Execution Lesson Stage - Substage sharing individual resolutions strategies } \\
\hline Q 39 & $a, b, c, e, f, g$ & $\begin{array}{l}\text { Has the teacher worked on everyone's participation in building } \\
\text { the solution to the problem? }\end{array}$ \\
\hline Q 40 & $\mathrm{a}, \mathrm{b}, \mathrm{c}, \mathrm{f}, \mathrm{g}$ & $\begin{array}{l}\text { Did the teacher check some different resolutions made by the } \\
\text { students? }\end{array}$ \\
\hline Q 41 & $a, b, c, f, g$ & $\begin{array}{l}\text { Did the teacher share some different resolutions made by the } \\
\text { students? }\end{array}$ \\
\hline \multicolumn{3}{|c|}{ Execution Lesson Stage - Substage students' evaluation } \\
\hline Q 42 & $c, f, g$ & $\begin{array}{l}\text { Has the teacher been concerned with assessing individual } \\
\text { student learning? }\end{array}$ \\
\hline
\end{tabular}




\begin{tabular}{c|c|l}
\hline Q 43 & c, f, g & $\begin{array}{l}\text { Did the teacher evaluate the success/failure of the problem text } \\
\text { understanding stage? }\end{array}$ \\
\hline Q 44 & b, c, f, g & $\begin{array}{l}\text { Did the teacher evaluate the success/failure of the problem } \\
\text { solving planning stage? }\end{array}$ \\
\hline Q 45 & c, f & $\begin{array}{l}\text { Did the teacher evaluate the success/failure of the mathematical } \\
\text { executing stage of the problem? }\end{array}$ \\
\hline Q 46 & c, f, g & $\begin{array}{l}\text { Did the teacher evaluate the success/failure of the problem } \\
\text { looking back stage? }\end{array}$ \\
\hline
\end{tabular}

Source: authors.

The Planning Stage aims at evaluating 16 aspects that should be concerned by the teacher, when drawing a class based on problem solving. The Execution stage analyzes the quality of the teacher's intervention in the conduction of the class and in consistency with the idealized planning. This stage is divided into 4 substages: problem presentation, solving process, sharing individual resolutions strategies, and students’ evaluation (Table 3).

Table 3 - Distribution of items of QAIPS.

\begin{tabular}{l|l|c}
\hline \multicolumn{2}{c|}{ Stage under review } & Number of evaluated items \\
\hline \multirow{4}{*}{ Planning } & problem presentation & 16 \\
\hline \multirow{4}{*}{ Execution } & solving process & 04 \\
\cline { 2 - 3 } & sharing solutions & 18 \\
\cline { 2 - 3 } & students' evaluation & 03 \\
\hline \multicolumn{2}{c}{ TOTAL } & 05 \\
\hline
\end{tabular}

Source: authors.

The items were evaluated in the same manner as the MQI (HILL et al., 2011). If a teaching element was present and if this presence was considered appropriate, it would be reported as "P-A", present-inappropriate, "P-I”, not present-appropriate, "NP-A”, not present-inappropriate, “NP-I”. There was, however, need to consider a fifth possibility: not applicable, "N-A", due to specificities of classes based on problem solving, and to observe the non-compliance of the four evaluation categories. By way of illustration, it is possible for students to express understanding of the problem of the text before the teacher take any initiative. In this case, it is not possible to say if his/her action was present/not present and appropriate/inappropriate in item 3 of the QAIPS. Moreover, it is possible that the teachers have not completed a full item or all times during class. In such cases, we 
think it is appropriate categorize in the light of what has occurred most of the time. The summary of the categories of analysis can be found in Table 4:

Table 4 -QAIPS’ categories.

\begin{tabular}{cll}
\hline Code & \multicolumn{1}{c}{ Description } & \multicolumn{1}{c}{ Characteristic } \\
\hline P-A & present-appropriate & The item was present and it was considered appropriate. \\
\hline P-I & present-inappropriate & The item was present and it was considered inappropriate. \\
\hline NP-A & not present-appropriate & $\begin{array}{l}\text { The item was not present and its absence was considered } \\
\text { appropriate. }\end{array}$ \\
\hline NP-I & not present-inappropriate & $\begin{array}{l}\text { The item was not present and its absence was considered } \\
\text { inappropriate. }\end{array}$ \\
\hline N-A & not applicable & $\begin{array}{l}\text { Failure to fit the four assessment categories above for the } \\
\text { specifics of problem-solving classes. }\end{array}$ \\
\hline
\end{tabular}

Source: authors.

Finally, it is important to highlight the shading viability of two items, i.e., items that will eventually be confused in its objectives, but that their separation is indispensable because there have been cases of one been satisfied and the other not. For example, in item 17, the teacher may have examined the familiarity of students with the context of the problem to verify understanding of words. In other cases, the teacher may have only checked the understanding of the words, but the context is still beyond the reach of his students, justifying the separation of items.

It remains for us to present empirical situations that have shaped the QAIPS and validating the instrument, the subject of the next topic object.

\section{SCENARIO FOR INSTRUMENT VALIDATION}

The validation of the instrument occurred in a scenario of classes planned and executed under the Lesson Study method. This method's cycle is divided into three main stages, according to Fernandez and Yoshida (2004): 1 - collaborative planning; 2 - execution of the plan elaborated in the first stage; 3 - discussion/evaluation of the implementation of the lesson, which are repeated according to the need for adjustments and enhancements. We consider the Lesson Study as a spiral (GAIGHER; SOUZA; WROBEL, 2017), a representation that conveys the idea that each new 
lesson planned-executed-reflected aggregates experiences to previous discoveries, providing accomplishments with a higher level of maturity.

The first stage of a Lesson Study is marked by setting goals and planning according to the school curriculum. In it, the teachers come together to discuss and plan together the purpose of that lesson (or a sequence of lessons). Thus, "this planning is of a meticulous and collaborative nature" (FERNANDEZ; YOSHIDA, 2004, p.7). The objective in question should focus on the learning of certain content, resulting in changes in attitudes, behavior improvement and the awakening of curiosity in students.

The second stage of Lesson Study - execution of the planned lesson - is characterized by the consummation of the plan drawn up jointly. In it, a teacher (usually the class conductor) runs the planning in its class, while the other teachers who participated in the preparation of the plan, act as observers of both the teacher's performance, as the impact on student learning, noting details that will subsidize the next step - reflection on the class.

Observers point out the answers, difficulties and facilities of the students, the teacher's attitudes and responses, goals achieved or not, necessity to carry out new planning, coherence between planning and execution, verification of familiarity and potentiality of the problem with the experiences of the students, diversity of strategies presented, among others, without interfering in the development of actions by the classroom teacher.

Then, they discuss and reflect on what was done in class by the same group of people, to check the previous stages and, possibly, improve the actions that broaden students' mathematical concepts and abilities, inaugurating new stage, planning-execution-reflection, at a higher level of maturity. In the first and third stages, the possible impacts of teacher's action on learning are discussed, as well as ingredients present throughout the study. They are used as a basis for the reformulation of the class and of the teacher's own practice. To go through the stages, teachers are led to reflect on various aspects of teaching, allowing a confrontation between theory and practice either in terms of mathematics or in teaching practice.

The classes that validated the QAIPS aimed to solve verbal problems of mathematics, understood as "those made by writing, using, above all, the natural language, possibly permeated by elements from the language of mathematics” (SOUZA; GUIMARÃES, 2015, p.137). In this 
context, it emerges the necessity of one another mathematical content, depending on the options of the students and the teacher.

More in detail, the efficiency and viability of the QAIPS was verified in six classes based on problem solving by mathematics teachers gathered for the planning and execution of lessons, guided by the method above. These classes were directed to the in-service training of mathematics teacher to idealize classes based on problem solving in a shared and reflective way.

The planning of the classes was composed of nine teachers dedicated on the lesson drawn based on certain mathematics problem. Then the same group elected an executor teacher of the class. Finally, immediately after the execution of the classes, the teachers' team met to discuss positive and negative aspects of planning and execution, and to propose adjustments to the new issue of class. This third moment, although composing the method, was not useful for the validation of the instrument.

The six meetings were recorded on video for playback to bring forward discussions that broaden the power of interpretation and validation. The in-training teachers did not know about the instrument and the authors were present but did not interfere in the progress of the lessons. To evaluate the classes, they watched all videos, pausing every five minutes, to answer all 46 items as adequate or not, appropriate or not and so on. One author did not have access to the response of the other, as it is done in such analysis to guarantee the validity of the instrument. The instrument was considered valid since the answers were the same for the authors.

\section{ANALYSIS AND RESULTS OF SOME ITEMS FROM THE QAIPS}

Due to the limitations of space of this article, will better than ' 11 in academic texts show only some events observed in the six lessons formatted by method Lesson Study and assessed by QAIPS. The teachers' names have been omitted in order to protect their identities and comply with research ethics, being replaced by codenames.

\section{About Q3, Q18 and Q19:}

Teacher Akira planned a lesson to the next problem ${ }^{6}$ :

6 This problem was extracted from Viana, A., Sônego, D.; Mendes, R. (2014). Coragem, estúpido! Revista Cálculo. ano 4. n.40. Editora Segmento, São Paulo, SP. p.18-36. 
A non-flying ant lives on the surface of a solid cube with one meter edge. Starting from vertex $\mathrm{G}$ towards vertex $\mathrm{A}$, what is the minimum distance traveled by the ant?

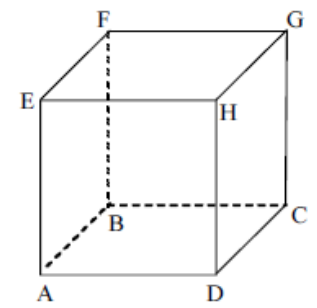

In the re-planning and re-execution, the words "non-flying”, "solid”, “edge” and "vertex" were checked, because they were able to block the understanding of the problem by the students, which was considered $P$-A (present and appropriate) by authors.

\section{About Q2, Q17, Q 21, Q26 and Q32}

Professor Sakura and her colleagues planned a class to the next problem:

My father told me that in 1938 he talked to his grandfather and observed that each one's age was expressed by the number of the last two digits of the years they had been born. So, when my father was born, how old was my grandfather?

In planning, several initial questions were provided to the solution process, which did not contribute for the reasoning flow of the students, such as: "Where do we start?; And now?; The problem is complete?”, considering Q21 as $P-I$ (present and inappropriate). Instead, Sakura showed a picture of the work "Waterfall" by Escher (Figure 2), because it is much admired by mathematicians for their patterns and symmetries, questioning students about aspects that were not related to the problem (Q32), associating the figure to an enigma. Be or not to be an enigma was something that did not help to manage the solution process, consuming time that should be devoted to the construction of reasoning by the group. This problem is considered thus as NP-I (not present and inappropriate).

7 This problem was extracted from http://www.somatematica.com.br/desafios/desafio76.php. 
Figure 2 - Waterfall, 1961 - Lithograph.

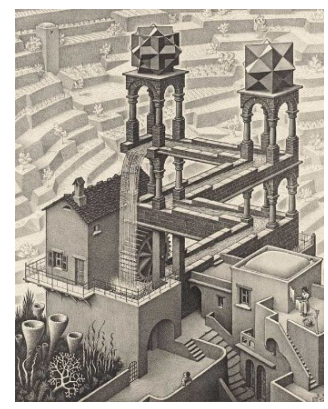

Source: http://www.mcescher.com/gallery/recognition-success/waterfall/

The problem of professor Sakura's group did not lend itself to mathematical learning content, but as application, featuring Q26 as $N$-A (not applicable).

Regarding the students' context with the problem, Sakura and his group, appropriately, did not plan to hold the conference, since there was familiarity of those students with the full text, receiving therefore the Q2 and Q17 an evaluation as NP-A (not present and appropriate) in this class.

\section{About Q24, Q29, Q39, Q40 and Q41}

Professor Hiroshi gave a lecture on the following problem ${ }^{8}$ :

You want to find out how many steps are visible on a escalator in movement. To do this, two people started to climb the escalator in movement together, one up one step at a time while the other climbed two steps at a time. At the top, the first person counted 21 steps while the second counted 28. With these data, these people were able to answer the question: how many steps are visible on this escalator in movement?

During its execution, Hiroshi valued the students' participation in the construction of the solution (Q39), as shown in cutout dialogue below:

Hiroshi: Is there any other data to consider in this problem, guys?

Student 1: I am considering that the escalator is rising...

Student 2: Is it possible that the escalator is going up and the person is going down?

Hiroshi: Can you people do some drawing to illustrate the escalator's situation? (Q24).

$<$ Student 2 shows the design to the teacher and the teacher repeats the design in the board.>

8 Problem extracted from http://www.somatematica.com.br/desafios/desafio12.php. 
Hiroshi: A question for you: on a escalator that is rising, how the steps are generated?

$<$ The students show in hands the movements of the escalator and start to collectively discuss this motion.>

As the problem developed, the students were called to the blackboard to present their solutions (Q40, Q41), as shown in the sequence of photos in Figure 3.

Figure 3 - Students sharing their solutions to the problem of the escalator.
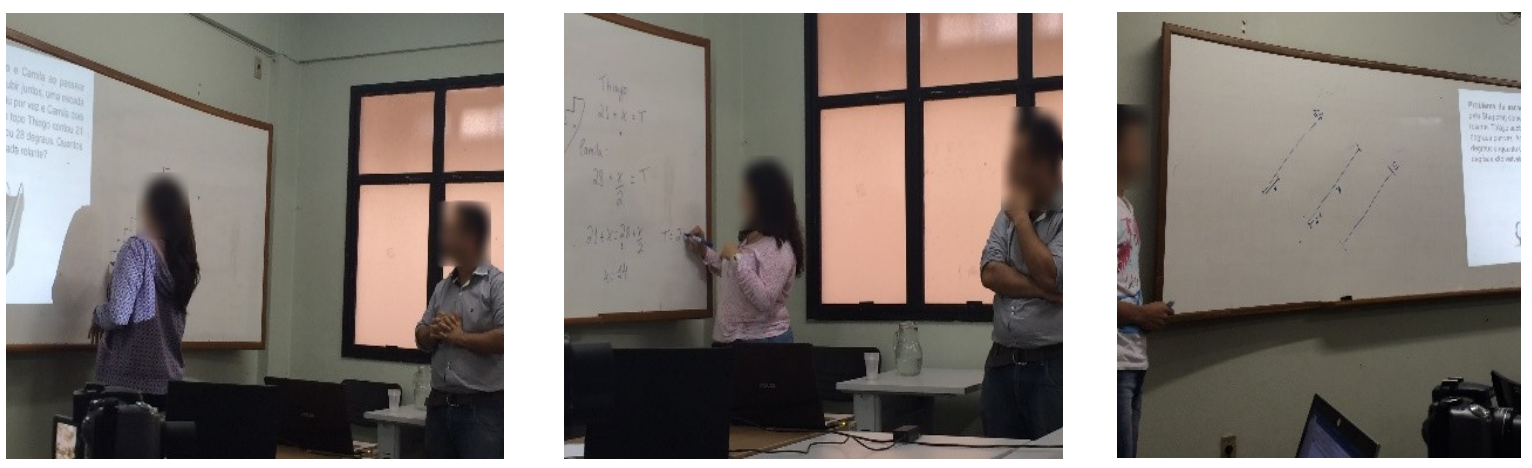

Source: authors.

All these actions of Hiroshi were considered P-A (present and appropriate) by the authors. However, the solution presented by one student on the board was incorrect, since the response of the problem was 42 steps (Figure 4). This fact was identified by Hiroshi, but despised as a learning opportunity for the class (Q29) being evaluated in this topic as NP-I (not present and inappropriate). In fact, the student dismissed in its calculations the appearance of not visible steps inherent in the automatic movement of the escalator.

Figure 4 - Solution of a student for Hiroshi's escalator problem. 


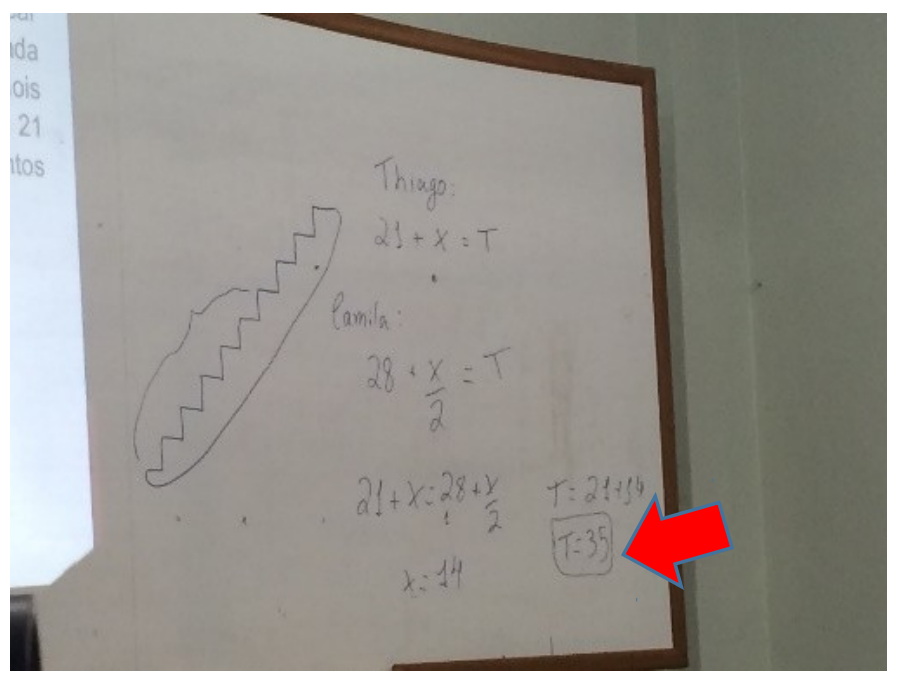

Source: authors.

\section{About Q24, Q25 and Q34}

Professor Yudi taught class on the following problem ${ }^{9}$ :

Imagine that you have a full cup of coffee of the very tasty black liquid and a tall glass full of milk, about 6 times the size of the cup. Dip a teaspoon into the coffee cup and pour its contents into the glass of milk. Then dip the same spoon into the glass that now has the mixture and return it to the coffee cup. After completing this operation, which of these statements is right?

1) There is more coffee in the milk glass than milk in the coffee cup.

2) There is as much coffee in the milk glass as milk in the coffee cup.

3) There is more milk in the coffee cup than coffee in the milk glass.

Explain it.

Yudi adopted an imagery strategy to represent the displacement of liquid from a container to another. Since all demonstrated understand the scheme, Yudi went to the algebraic representation in an attempt to generalize the solution (Q24 and Q25), considering $P-A$.

We highlight that, in proposing the problem to his peers, in a class execution immediately prior to the planning by Lesson Study, Yudi represented two different variables with the same letter (x), one of them meaning the amount of coffee in the spoon and the other meaning the spoon volume, causing mental confusion in his peers. This is an example of the potential of QAIPS in item 9 Problem extracted from ROSÁRIO, P.; NUNÉZ, J. C.; GONZÁLEZ-PIENDA, J.. Cartas de Gervásio ao Seu Umbigo: comprometer-se com o estudar no ensino superior. Adaptação à versão brasileira de Soely Aparecida Jorge Polydoro e Fernanda Andrade de Freitas. São Paulo: Almedina, 2015, p.79. 
Q34, which would be evaluated as NP-I. For better understanding, we emphasize that a part of the dialogue between Yudi and his peers in solving the problem. It is emphasized that Yudi did not know how to write algebraically the equality between the volume of the spoon and the volume of coffee that initially leaves the cup (italic by authors):

\section{[...]}

Yudi: $\quad x$ is the amount on the spoon. The volume on the spoon. So I took $\quad x \quad$ coffee and put there at the milk, right?! When I come back, back a mixture. What percentage < misused term by Yudi $>$ of this blend of coffee and milk? It would be $x$ amount of milk. But, within the milk has coffee. How much coffee? The amount that I took here < show the glass $>$ would be $\alpha$. Agree? Or not?

Teacher A: Once again you called $\quad x$ quantity on the spoon...

Teacher B: Your variables are confused...

Teacher H: If $\quad x$ is volume, it is the same in going and coming.

Teacher A: And so it is better to call $x$ the amount of coffee.

Yudi: But it was the spoon that I took, right? $x$, right? Which is what fits in my container spoon?

Student B: $\quad x$ is the volume of coffee?

Yudi: Yes, $\quad x$ is the volume of coffee because if $\quad x$ is the amount in the spoon and I

took one spoon of coffee, then there is $\quad X$ amount of coffee. Right? I put $\quad x$ amount of coffee in the milk. When I pick up the spoon back, I picked up $x$ amount of milk with coffee.

Teacher M: Yes, $\quad x \quad$ is the amount on the spoon.

Teacher B: So, the volume in the first situation is equal to the volume of coffee. When back, the volume is equal to the amount of coffee plus a quantity of milk.

Yudi: Milk with coffee. Then ask yourself the following: $x$ pure coffee is going. Return the same amount $\quad x$ of milk with coffee. Let's split within that $\quad x$ is milk and that is coffee. When I take the spoon off the glass, lies $x$ in the glass?

Teacher H: Depends. Who is $x$ ?

Yudi: The volume of coffee.

Teacher H: No, the volume of the spoon.

Yudi: Yes, but the volume of the spoon was the volume of coffee, wasn't it? And I threw the coffee in the glass, right?

Teacher A: What is missing if you set one variable for coffee and another for milk because the volume removed remains the same independent if you have milk or coffee.

Yudi: Because of that I have called $\quad x \quad$ pure coffee and $x$ milk with coffee.

At that time, the group interferes and suggests that Yudi writes “ $\mathrm{x}=$ amount of coffee" and " $\mathrm{y}=$ quantity of milk”, and “V = volume of the spoon”, as shown in Figure 5. 
Figure 5 - Solution of Yudi.

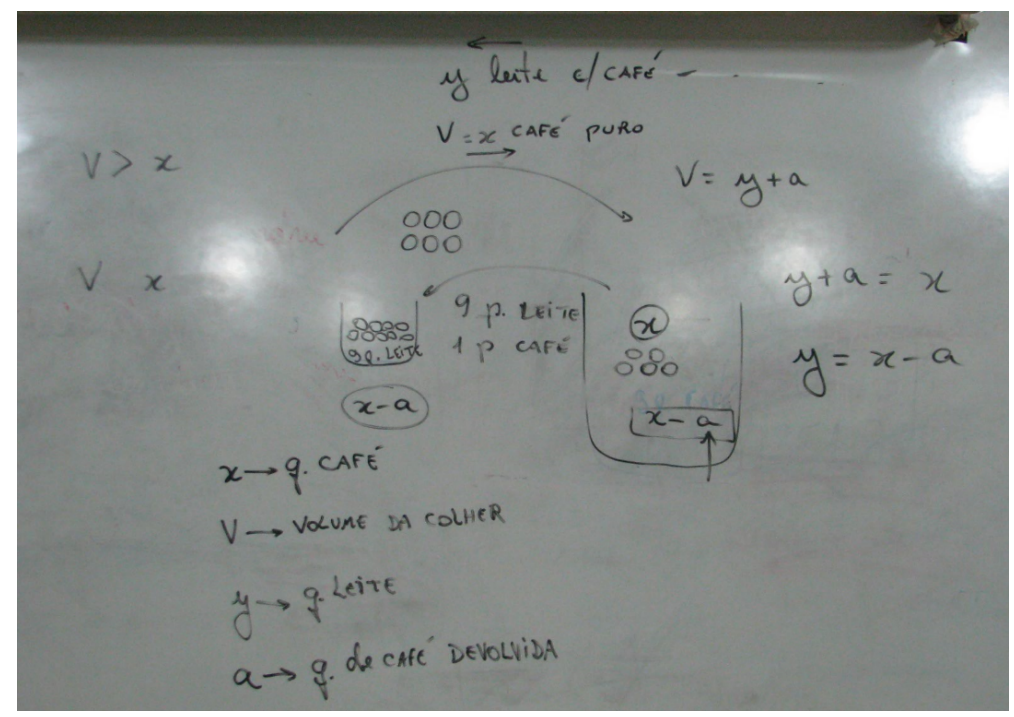

Source: authors.

In the Yudi case, such confusion could be corrected in the collaborative lesson planning, avoiding the error in the lesson for its students, as it happened.

\section{CONCLUSIONS AND INDICATIONS FOR FUTURE STUDIES}

The research has shown that the quality of teaching in mathematics classes based on problem solving, on the one hand, must have ingredients that any school classroom requires predict obstacles in understanding (Q3), predict reactions and responses (Q5), worry about multiple mental representations (Q8), plan how to evaluate the success/failure of the students (Q14), do not ask broad questions (Q20, Q21), consider students' mistakes (Q29), for example -, on the other hand, should consider the specificities of a work done with problem solving activity - has criteria for choosing the problem (Q1), plan more than one problem solving strategy (Q7), find more efficient solutions (Q11), plan and evaluate the success/failure of the students with four stages that problem solving has (Q13, Q14, Q15, Q16), find out if the students know a similar problem (Q22), consider the looking back stage (Q46), these were some examples.

The bibliographic search brought to the forefront 46 items that answer how we can evaluate the quality of teaching a class in solving Mathematics problems, gathered by the authors in an 
instrument called QAIPS. It remained to validate this instrument in classes of this type. Thus, the authors evaluated the teaching of four Mathematics teachers, each one conducting a lesson based on a verbal problem of Mathematics in a Lesson Study environment. The validation of the 46 items of QAIPS occurred with systematic individual analyzes of the class recordings by the authors. The comparison of these analyzes resulted in coincidence in the evaluations of the authors whose judgment for each item could take one of five possibilities: present and appropriate, present and not appropriate, not present and appropriate, not present and not appropriate and not applicable. The tuning in the trials was the support we needed for QAIPS validation.

However, we do not intend to exhaust the evaluation of the quality of a class with the 46 items that emerged from the present investigation, but, on the contrary, we seek to be opportune for the contribution for the pre-service/in-service training of/in the practice of mathematics' teachers in that they promoted the opportunity to discuss and intervene significantly on teaching practice in this important bias of the Mathematics discipline - the problem solving.

Our future challenge is associating to this mapping some measure that quantifies such actions validating the quantitative instruments, or MQIMPS - Measuring the Quality of Instruction in Mathematics Problem Solving.

\section{ACKNOWLEDGMENTS}

The authors thank the Federal Institute of the Espírito Santo for the financial support, provided by PRPPG Notice 02/2016 - Institutional Program for Scientific Dissemination (PRODIF). We are also grateful to Professors Hellen Castro de Almeida Leite and Bruna Dalle Prane for the participation and contribution in some of the classes.

\section{REFERENCES}

ABRANTES, P. Mudam-se os tempos, mudar-se-ão as vontades? Educação e Matemática, Lisboa, APM , n.8, p.1-2. Editorial, $1^{\circ}$ trimestre de 1989 (1989a).

ABRANTES, P. Um (bom) problema (não) é (só)... Educação e Matemática, Lisboa, APM, n 8(4), 7-10. 1989b. 
ALLEVATO, N. S. G.; ONUCHIC, L. de L. R. Ensino-Aprendizagem-Avaliação de Matemática: por que através da resolução de problema?. In: ONUCHIC, L. de L. R. et al. (Org.). Resolução de Problemas: Teoria e Prática. São Paulo, Paco Editora. 2014. p.35-53.

BALDIN, Y. Y. O significado da introdução da metodologia japonesa de lesson study nos cursos de capacitação de professores de matemática no Brasil. In: anais do XVIII Encontro Anual da SBPN e Simpósio Brasil-Japão (SBPN 09). São Paulo, SP, 2009.

BALL, D. L.; BASS, H. Making mathematics reasonable in school. In: J. Kilpatrick, W. G.

MARTIN; D. SCHIFTER (Eds), A research companion to Principal and Standards for School Mathematics. Reston, VA: National Council of Teachers of Mathematics. 2003. p.27-44.

BALL, D. L.; THAMES, M. H.; PHELPS, G. Content Knowledge for Teaching: What Makes it Special. Journal of Teacher Education, v. 50(1), p.389-407. 2008.

BLAKERS, A. L. Change in mathematics education since the late 1950's-ideas and realisation Australia. Educational Studies in Mathematics, 9, 147-158. 1978.

BOGDAN, R.; BIKLEN, S. Investigação Qualitativa em Educação - uma introdução à teoria e aos métodos. Porto: Porto Editora. 1994.

BRASIL. Parâmetros Curriculares Nacionais: Ensino Médio. Brasília: MEC/SEF. 2000. CLANDININ, D. J. Classroom practice, teacher images in action. London: The Falmer Press. 1986.

CLANDININ, D. J. Personal practical knowledge: a study of teacher's classroom images. Curriculum Inquiry, v.14(4), p.361-385. 1985.

DIAS SOBRINHO, J.; RISTOFF, D. I. (Org.). Avaliação e compromisso público: a educação superior em debate. Florianópolis: Insular, 2003.

ELBAZ, F. Teacher thinking, a study of practical knowledge. London: Croom Helm. 1983.

FENSTERMACHER, G. The knower and the known: the nature of knowledge in research on teaching. Review of Research in Education, v. 20, p.3-56. 1994.

FERNANDEZ, C.; YOSHIDA, M. Lesson Study: a japanese approach to improving mathematics teaching and learning. New Jersey, EUA: Autores Associados. 2004.

FUJII, T. Implementing japanese lesson study in foreign countries: misconceptions reviewed. Mathematics Teacher Education and Development, v. 16(1), p.2-18. 2014.

GAIGHER, V. R.; SOUZA, M. A. V. F.; WROBEL, J. S. Planejamentos colaborativos e reflexivos de aulas baseadas em resolução de problemas verbais de matemática. Vidya (no prelo). 
HILL, H. C. et al. Measuring the Mathematical quality of instruction: learning mathematics for teaching project. Journal for Mathematics Teacher Education, v. 14(1), p.25-47. 2011.

ISODA, M.; OLFOS, R. El enfoque de resolucion de problemas: en la enseñanza de la Matemática a partir del estudio de classes. Ediciones Universitarias de Valparaiso: Valparaiso. 2009.

JORGENSEN, D. L. Participant observation: a methodology for human studies. Newbury Park, CA: Sage Publications. 1989.

MINISTÉRIO DA EDUCAÇÃO. Programa de Matemática do Ensino Básico. Lisboa: Ministério da Educação. 2007.

NATIONAL COUNCIL OF TEACHERS OF MATHEMATICS. An agenda for action. Reston, VA: NCTM. 1980.

POLYA, G. How to solve it. 2.ed. Princeton, New Jersey: Princeton University Press. 1973.

PONTE, J. P. et al. Exercícios, problemas e explorações: perspetivas de professoras num estudo de aula. Quadrante, v. 24(2), 111-134, 2015.

PONTE, J. P. Formação do professor de Matemática: perspetivas atuais. In: Ponte, J. P. (Org.), Práticas Profissionais dos Professores de Matemática. Lisboa: Instituto de Educação da Universidade de Lisboa. 2014. p.343-360.

PURAKAM, O. Change in mathematics education since the late 1950's - Ideas and realisation Thailand. Educational Studies in Mathematics, v. 9, p.331-337. 1978.

REVUZ, A. Change in mathematics education since the late 1950's-ideas and realisation france Educational Studies in Mathematics, v. 9, p. 171-181. 1978.

SCHOENFELD, A. Porquê toda essa agitação acerca da resolução de problemas? In ABRANTES, P.; LEAL, L. C.; PONTE, J. P. (Eds.), Investigar para aprender matemática. Lisboa: APM e Projecto MPT. 1996. p.61-72.

SCHÖN, D. Formar professores como profissionais reflexivos. In: NÓVOA, A. (Ed.). Os professores e a sua formação. Lisboa: D. Quixote. 1992. p.79-91.

SCHÖN, D. The reflective practitioner: how professionals think in action. London: Avebury. 1991.

SHULMAN, L. S. Those who understand: knowledge growth in teaching. Educational Researcher, v.15(2), p.4-14.1986. 
SOUZA, M. A. V. F. de. Impactos da gestão de aulas baseadas em problemas verbais de Matemática sobre a aprendizagem. Educar em Revista, n.64, abr-jun, 231-246, 2017.

SOUZA, M. A. V. F. de; GUIMARÃES, H. M. A formulação de problemas verbais de matemática: porquê e como. Quadrante, v. 24(2), p.135-162. 2015.

SOUZA, M. A. V. F. de; SOUZA, S. F. de. Enunciados verbais de problemas de matemática e representações mentais: uma discussão. Educação \& Linguagem, v.19, n.1, 205-221, 2016.

VANDENBOS, G. R. (Org.). Dicionário de Psicologia. Tradução de Daniel Bueno, Maria Adriana Veríssimo Veronese e Maria Cristina Monteiro. Porto Alegre: Artmed, 2010.

WROBEL, J. S. et al. Inquiries in problem solving with contributions from lesson study. In:

Proceedings of PME 40. Szeged: Hungary. Vol.1, p.341. 2016. 